ZOOLOGIA 32 (2): 157-161, April 2015

http://dx.doi.org/10.1590/S1984-46702015000200007

\title{
Description of the males of Lincus singularis and Lincus incisus (Hemiptera: Pentatomidae: Discocephalinae)
}

\author{
Aline S. Maciel ${ }^{1}$, Thereza de A. Garbelotto ${ }^{1}$, Ingrid C. Winter ${ }^{1}$, \\ Talita Roell' \& Luiz A. Campos ${ }^{1,2}$
}

\begin{abstract}
${ }^{1}$ Departamento de Zoologia, Universidade Federal do Rio Grande do Sul. Avenida Bento Gonçalves 9500, Agronomia, 91501-970 Porto Alegre, RS, Brazil.

2Corresponding author. E-mail: luiz.campos@ufrgs.br
\end{abstract}

\begin{abstract}
The Neotropical Lincus Stål, 1867 includes 35 species, thirteen of which are known only from females. Several species are vectors of Phytomonas staheli McGhee \& McGhee, 1979, a trypanosomatid parasitic in palm-trees in South America that causes hart-rot, sudden and slow wilt diseases. The hitherto unknown males of $L$. singularis Rolston, 1983 ("swollen head" species group found in the oil palm Elaeis guineensis Jacq.), and L. incisus Rolston, 1983 ("hatchetlobed" species group; found in the coconut tree Cocos nucifera L.), are described with emphasis on the morphology of the genitalia, and taxonomic remarks are provided. Males of $L$. singularis can be distinguished from other species included in "swollen head" group by their pronotal lobes with anterior and posterior margins subparallel and projected laterally from the eye margin, while males of $L$. incisus can be distinguished from the species of the "swollen head" group by an obtuse projection with a deepest incision and several additional diagnostic characters of the genitalia.
\end{abstract}

KEY WORDS. Genitalia; morphology; Ochlerini; stink bugs; taxonomy.

Lincus Stål, 1867 is the richest genus of Ochlerini, comprising 35 species (CAmpos \& Grazia 2006). Even though the genus was described in the 19th century (STÅL 1867), most of its 25 species were described in the late 20th century (RoLsTon 1983, 1989, Doluing 1984), and 13 of them are known only from one sex (Rolston 1983). Species of Lincus are found mostly in the Amazon region. There are a few exceptions to this, for instance Lincus lobuliger Breddin, 1908, recorded from the Brazilian Atlantic Forest and Lincus anulatus Rolston, 1983 and Lincus discessus (Distant, 1900) from Central America (Rolston 1983). Several species are sympatric in different countries. Geographic records of Lincus are particularly rich in Peru due to the extensive surveys on native palms carried out during the 1980's (Couturier \& Kahn 1989, 1992, Llosa et al. 1990). Sixteen species occur in that country, including Lincus singularis Rolston, 1983, although it has never been collected on Elaeis guineensis Jacq. Suriname comes next in terms of species richness in the Amazon region (RoLsTon 1983, 1989, Dolling 1984), with six species, including Lincus incisus Rolston, 1983.

The association of pentatomids with the transmission of Phytomonas staheli McGhee \& McGhee, 1979, a trypanosomatid parasitic in plants, has been known for a long time and is well documented (for a review see CAMARgo 1999 and Mitchell 2004). Several species of Lincus play a major role as vectors of hart-rot, and of sudden and slow wilt (also called Marchitez sorpresiva in
Spanish-speaking countries) diseases in palm trees (Arecaceae) in South America, being of economic interest in crops of $E$. guineensis (African oil palm) and Cocos nucifera L. (coconut) (DESMIER DE Chenon 1984, Couturier \& Kahn 1989, Perthuis et al. 1985, Panizzi et al. 2000, Di Lucca et al. 2013; for a review see Howard 2001). Although eleven species of Lincus have been reported on palm trees (HowARD 2001), the genus was not listed as a possible vector of oil palm diseases until the 1980's (COUTURIER \& KAHN 1992). Furthermore, transmission of Phytomonas trypanosomatids to palms has been documented in only six species, four of which transmit the parasite to E. guineensis: Lincus lethifer Dolling, 1984, L. lobuliger, Lincus tumidifrons Rolston, 1983, and Lincus spurcus Rolston, 1983 (CAMARGo 1999, Di LuCCA et al. 2013).

In 2009 , the corresponding author received, for identification, specimens of Lincus collected from E. guineensis palm trees from Palmas del Espino S.A., Peru. These specimens were identified as $L$. spurcus and L. singularis, and included the only known males of the latter. Moreover, during the course of this study, we located males of $L$. incisus among specimens of Ochlerini received during the 1990's, two of which from $C$. nucifera crops cultivated by Sococo S.A., Moju, Pará State, Brazil. For the first time, L. singularis and L. incisus are reported from oil palm and coconut trees, respectively, and their males are described and illustrated for the first time, with emphasis on the morphology of genitalia. 


\section{MATERIAL AND METHODS}

Five males and one female of $L$. singularis and three males and three females of $L$. incisus were examined in this study. The species were identified based in a revision by ROLSTON (1983). Observation of specimens, dissection and preservation followed Garbelotto et al. (2013). Measurements are in millimeters (mm) and follow mainly Garbelotto et al. (2013) and Rolston (1983) for: length and width of eye and pronotal lobe, and interocellar distance. The terminology of BAKER (1931), Dupuis (1970), Campos \& Grazia (2006) and Garbelotto et al. (2013) were adopted for genitalic structures. Photographs were taken using a Nikon AZ100M stereomicroscope and NIS-Elements Advanced Research software. Drawings were made under a stereomicroscope Leica MZ12 coupled with camera lucida and were vectored using Adobe Illustrator. Whenever possible, collection data were georeferenced following GARBELOTTO et al. (2013); coordinates are in decimal degrees.

Collections' acronyms follow EvenHuIs (2014). Voucher specimens are deposited in the entomological collection of the Departamento de Zoologia at Universidade Federal do Rio Grande do Sul (UFRG), Porto Alegre, RS, Brazil.

\section{TAXONOMY}

\section{Lincus singularis Rolston, 1983 \\ Figs. 1-9}

Lincus singularis Rolston, 1983: 1, 4, 5, 18-20, Figs. 34-35 (female holotype from Chauchamayo, Peru, deposited in USNM 76690, not examined, no paratypes); Couturier \& Khan, 1992: 719 (map); Campos \& Grazia, 2006: 153 (list).

Description of the male. The color of males is dark brown to fuscous and the general morphology is similar to that described for females by Rolston (1983) (Fig. 1). Genitalia. Pygophore oval, opening of genital cup narrow. Dorsal rim uniformly concave (Fig. 2, dr), bearing 1+1 tufts of setae lateral to segment X. Posterolateral angles rounded, projected distinctly beyond the ventral rim, depressed dorsally (Fig. 2, pa). Basal $1 / 3$ of segment $X$ membranous, lateral margins sinuous tapering to apex (Fig. 2, X). Ventral rim V-shaped, with setae along margin (Fig. 3, vr). Ventral surface tumescent on disc, with 1+1 lateral sulci following ventral rim (Fig. 3, t); ventral surface of posterolateral angles tumescent (Fig. 3). Parameres inconspicuous and covered by segment $\mathrm{X}$, attached to the articulatory apparatus of phallus, subtriangular in lateral view, bearing a dorsal dense tuft of setae on apex (Figs. 46). Phallus. Phallotheca globose (Figs. 7-9, ph), strongly sclerotized. Vesica longer than the combined lengths of phallotheca and ductus seminis distalis (Figs. 7-9, v, ds), bearing an dorsal subtriangular process posteriorly directed (Figs. 7-9, dp), and 1+1 lateral processes short and truncate (Figs. 7$9,1 p)$. Free portion of ductus seminis distalis very short, about half the length of the inner portion, projecting ventrad of vesica before the lateral processes (Figs. 7-9, ds).

Male. Measurements $(n=5)$. Total length $10.75 \pm 0.29$ (10.37-11.00); width of abdomen $6.62 \pm 0.36$ (6.12-7.00); head length $1.67 \pm 0.08$ (1.57-1.76); head width $2.24 \pm 0.10$ (2.142.39); eye length $0.50 \pm 0.03$ (0.47-0.55); eye width $0.55 \pm 0.02$ (0.52-0.57); interocellar distance $1.20 \pm 0.03$ (1.17-1.2); interocular distance $1.21 \pm 0.06$ (1.13-1.26); pronotum length $2.17 \pm 0.14$ (1.95-2.27); pronotum width $5.66 \pm 0.19$ (5.42-5.90); length of pronotal lobe $0.23 \pm 0.03(0.20-0.27)$; pronotal lobe width $0.17 \pm 0.02(0.15-0.20)$; scutellum length $4.27 \pm 0.25$ (3.91-4.60); scutellum width $3.55 \pm 0.13$ (3.39-3.72); length of antennomers: I $0.77 \pm 0.03(0.75-0.80)$; II $0.82 \pm 0.03$ (0.77$0.85)$; III $1.01 \pm 0.04$ (0.97-1.07); IV $1.42 \pm 0.04$ (1.37-1.45); V $1.81 \pm 0.11$ (1.62-1.92); length of labial segments: I $1.28 \pm 0.11$ (1.12-1.37); II $2.36 \pm 0.09$ (2.25-2.37); III $1.87 \pm 0.03$ (1.82-1.9); IV $1.79 \pm 0.06$ (1.75-1.90).

Material examined. Peru, Tocache: 5 males and 1 female, San Martin (Palmas del Espino S.A., Cultivo Palma Aceitera, parcela A11a [-8.41; -76.41] $500 \mathrm{~m}$ a.s.l.), 2009, E. Trindad leg. Distribution. Peru, Cusco and San Martín regions.

Remarks. Although no phylogenetic hypothesis has been advanced for species of Lincus, the genus was recovered in the Herrichella Distant, 1911 clade in a cladistic analysis of the Ochlerini (CAmpos \& GRAZIA 2006). The relationship between Lincus and the other members of the clade, however, remained unresolved. More recently, the genus (represented by $L$. lobuliger) was recovered as the sister group of the remaining taxa of the Herrichella clade in the phylogenetic analysis of Garbelotto et al. (2013). The monophyly of the genus, however, remains to be tested. Several species of Lincus are recognizable by their well-developed pronotal lobes, and all known males have tubular proctiger and reduced parameres (ROLSTON 1983, 1992). These characters were not used in the phylogenetic studies mentioned above. Regarding the phylogenetic relationships among the species of Lincus, Rolston (1983) placed L. singularis along with Lincus parvulus (Ruckes, 1958) and L. tumidifrons in the "swollen head" informal group of species ("species group of convenience" sensu RoLston 1983). This group was characterized by having a tumid vertex. Some features of the pygophore of $L$. singularis are consistent with Rolston's proposal to place the species in it, e.g. the ' $\mathrm{V}$ ' shape of the ventral rim of the pygophore; subrectangular proctiger with acute apex; and globose phallotheca, the latter also observed in L. tumidifrons. Lincus singularis can be differentiated from the other species in the "swollen head" group by having the anterior and posterior margins of the pronotal lobes subparallel and each lobe projected laterad of its corresponding eye; the vertex of head not as tumid as in $L$. parvulus and $L$. tumidifrons (Fig. 1; for L. parvulus and L. tumidifrons see RoLsTON 1983, Figs. 30 and 36); and the ventral opening of the pygophore is narrower than in those species (Fig. 3, vr; for $L$. parvulus and L. tumidifrons see Rolston 1983, Figs. 32 and 41). 

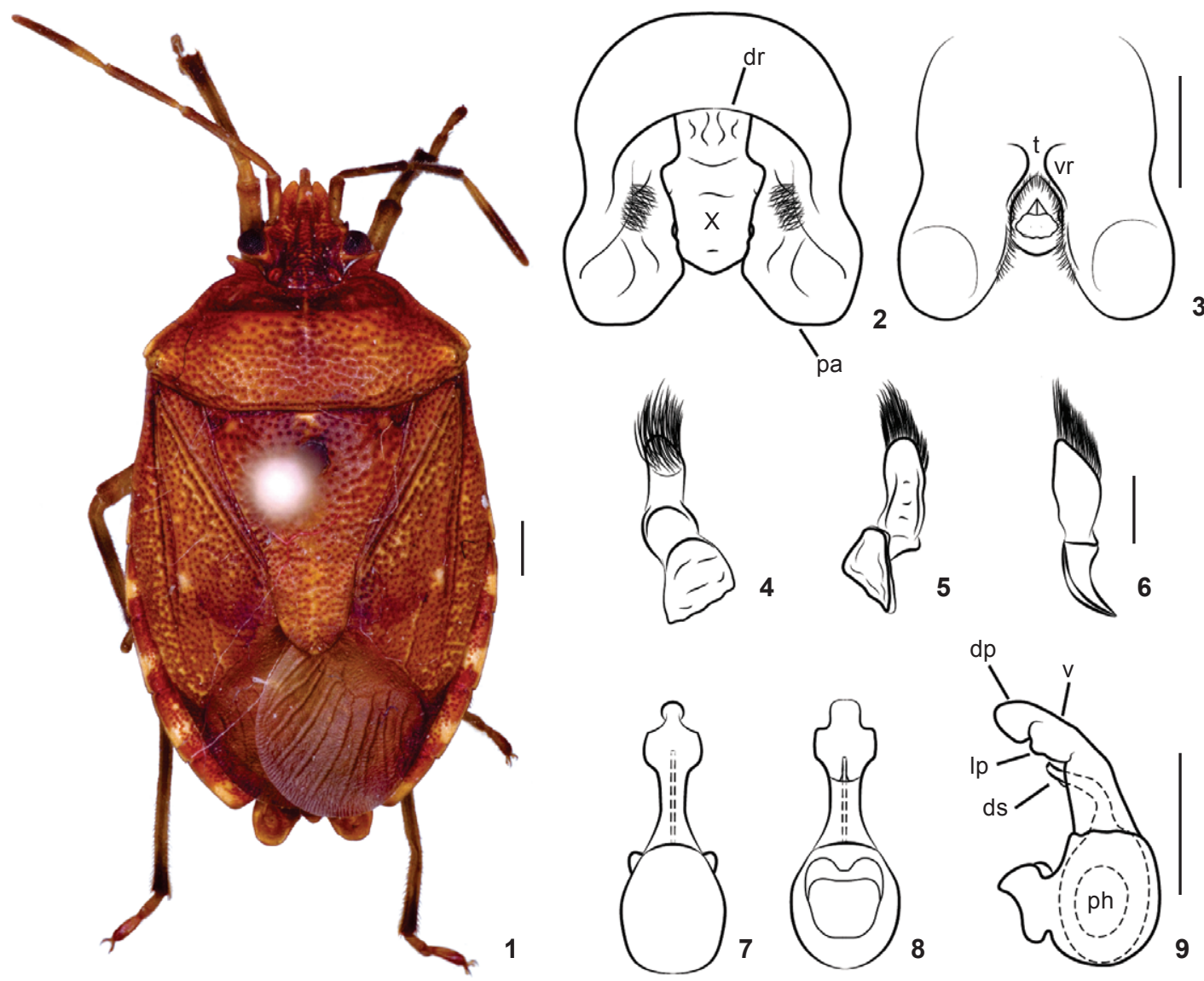

Figures 1-9. Male of Lincus singularis: (1) habitus in dorsal view; (2-3) pygophore: (2) dorsal view; (3) ventral view; (4-6) left paramere: (4) dorsal view; (5) ventral view; (6) lateral view; (7-9) phallus: (7) anterior view; (8) posterior view; (9) lateral view. (dp) Dorsal projections, (dr) dorsal rim, (ds) ductus seminis distalis, (Ip) lateral projection, (pa) posterolateral angles, (ph) phallotheca, (t) tumescent area, $(v)$ vesica, $(v r)$ ventral rim, $(X)$ segment $X$. Scale bars: $1-3=1 \mathrm{~mm}, 4-9=0.5 \mathrm{~mm}$.

\section{Lincus incisus Rolston, 1983}

Figs. 10-18

Lincus incisus Rolston, 1983: 1, 3, 4, 9-10, Figs. 8-9 (female holotype from De Mapane, Suriname, deposited in RMNH, not examined, no paratypes); Campos \& Grazia, 2006: 153 (list).

Description of the male. The fuscous general color of male and its general morphology, including the anterolateral margins of pronotum expanded in obtuse angle, posterior to pronotal lobes, are as described for females by Rolston (1983) (Fig. 10). Genitalia. Pygophore subrectangular. Surface with short setae. Dorsal rim concave, bearing setae lateral to segment $\mathrm{X}$ (Fig. 11, dr). Posterolateral angles obtuse (Fig. 11, pa), depressed, with 1+1 median projections (Fig. 11, mp). Segment X sclerotized, ventrally directed; apex expanded and flattened (Fig. 11, $\mathrm{X}$ ); anal opening circular, and genital opening in longitudinal slit, both at ventral surface (Fig. 12). Ventral rim concave, with setae along the margin, medially carinated (Fig. 12, vr). Ventral surface tumescent on disc, with 1+1 lateral sulci following ventral rim (Fig. 12, t). Parameres inconspicuous, attached to the articulatory apparatus of phallus, subrectangular and with an apical tuft of setae (Figs. 13-15). Phallus. Phallotheca globose, strongly sclerotized (Figs. 16-18, ph). Vesica elongated, medially narrowed, longer than the combined lengths of phallotheca and ductus seminis distalis (Figs. 16-18, v); with one globose dorsal projection posteriorly directed (Figs. 16-18, dp); 1+1 lateral globose projections, posteriorly directed (Figs. 16-18, lp); posterior projection truncated, bearing ductus seminis distalis (Figs. 16-18, pp). Ductus seminis distalis antero-dorsally arched toward the projections of vesica (Fig. 18, ds).

Measurements $(n=3)$. Total length $12.55 \pm 0.79(11.86$ 13.42); width of abdomen $6.77 \pm 0.32$ (6.46-7.10); head length $2.18 \pm 0.11$ (2.06-2.28); head width $2.63 \pm 0.06$ (2.56-2.68); eye length $0,60 \pm 0.03$ (0.57-0.63); eye width $0.78 \pm 0.03$ (0.75$0.82)$; interocellar distance $0.70 \pm 0.01$ (0.69-0.71); interocular distance $1.12 \pm 0.05$ (1.07-1.15); pronotum length $3.47 \pm 0.18$ 

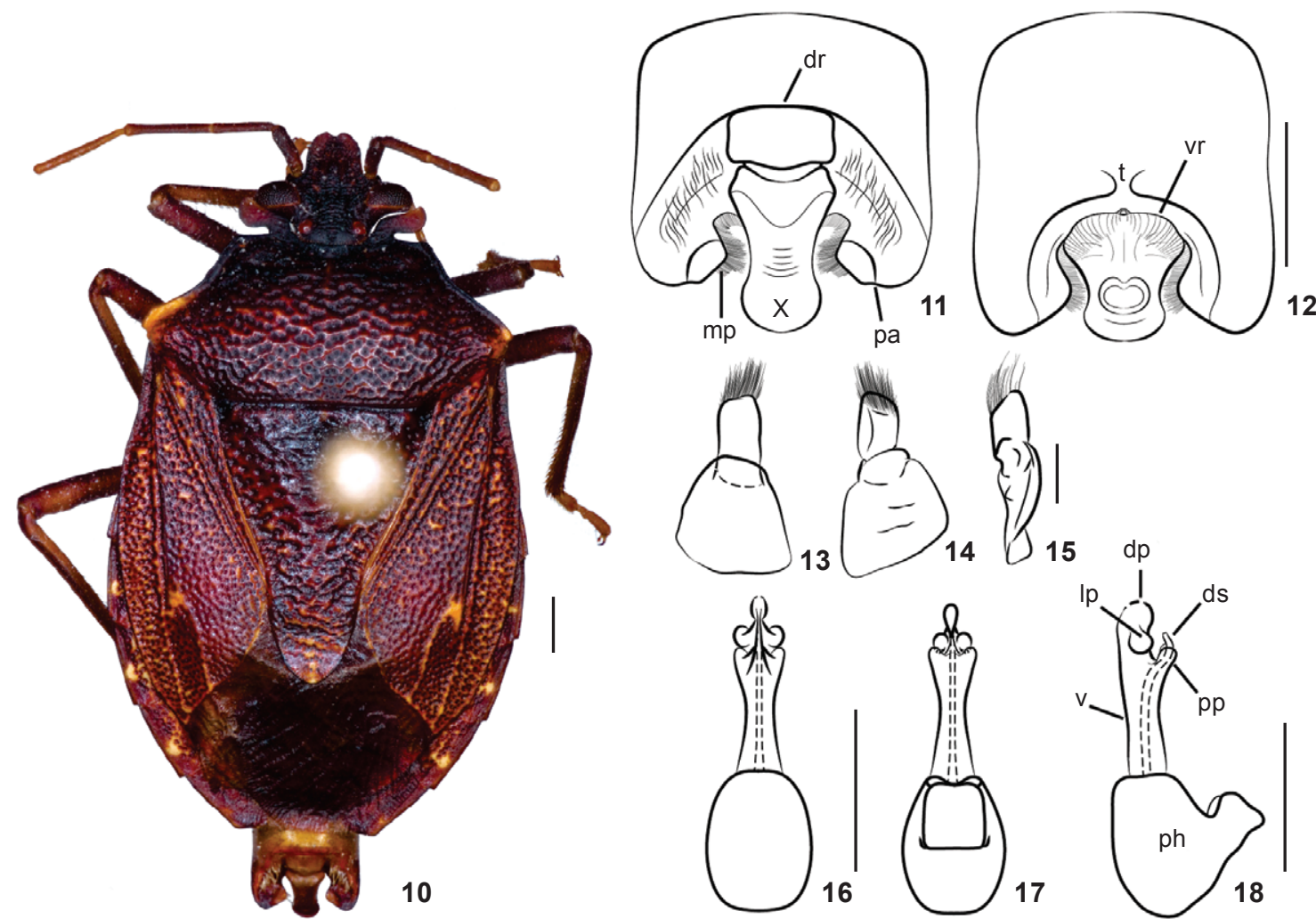

Figures 10-18. Male of Lincus incisus: (10) habitus in dorsal view; (11-12) pygophore: (11) dorsal view; (12) ventral view; (13-15) right paramere: (13) dorsal view; (14) ventral view; (15) lateral view; (16-18) phallus: (16) anterior view; (17) posterior view; (18) lateral view. (dp) Dorsal projections, (dr) dorsal rim, (ds) ductus seminis distalis, (Ip) lateral projection, (mp) median projection, (pa) posterolateral angles, (ph) phallotheca, $(\mathrm{t})$ tumescent area, $(\mathrm{v})$ vesica, $(\mathrm{pp})$ posterior projection, (vr) ventral rim, $(\mathrm{X})$ segment $\mathrm{X}$. Scale bars: 10$12=1 \mathrm{~mm}, 13-18=0.5 \mathrm{~mm}$.

(3.27-3.59); pronotum width $6.01 \pm 0.18$ (5.82-6.17); length of pronotal lobe $0.41 \pm 0.02(0.40-0.44)$; pronotal lobe width 0.85 \pm 0.02 (0.80-0.84); scutellum length $4.45 \pm 0.30$ (4.12-4.70); scutellum width $3.65 \pm 0.08$ (3.55-3.70); length of antennomers: I $0.97 \pm 0.04$ (0.92-1.00); II $1.12 \pm 0.08$ (1.07-1.21); III $1.42 \pm$ 0.07 (1.35-1.50); IV $1.38 \pm 0.20$ (1.2-1.56); V $1.78 \pm 0.00$ (1.781.78); length of labial segments: I $1.35 \pm 0.70$ (1.28-1.42); II $2.43 \pm 0.14$ (2.34-2.60); III $1.97 \pm 0.14$ (1.85-2.13); IV $1.66 \pm$ 0.05 (1.63-1.72).

Material examined. Brazil, Amazonas: 3 females, São Miguel da Cachoeira (Cachoeira do Tucano - Pico da Neblina), X.2007, Nogueira \& Candiani leg.; Pará: 2 males, Moju (Fazenda Sococo) [-2.11; -48.00], 01.XII.1995, P. Lins leg.; 1 male, Tucuruí (Rio Tocantins) [-3.7; -49.7], 20.VII.1984, W. França leg.

Distribution: Suriname, Brazil (Amazonas and Pará States).

Remarks. Lincus incisus was placed, along with eight other species (Lincus convexus Rolston, 1983, Lincus croupius Rolston, 1983, Lincus fatigus Rolston, 1983, Lincus operosus Rolston, 1983, Lincus securiger Breddin, 1904, Lincus sinuosus Rolston, 1983, Lincus spathuliger Breddin 1908 and Lincus vandoesburgi Rolston,
1983), in the "hatchet-lobed" informal group of species (RoLSTON 1983). This placement was justified in view of the anterior pronotal angles resembling a hatchet blade in Lincus incisus. Males of $L$. incisus share some genitalic characters with males of L. convexus, $L$. securiger, $L$. sinuosus and $L$. vandoesburgi, such as the presence of $1+1$ median projections at posterolateral angles, ventrally directed; and an elongated phallus bearing apical projections. The ductus seminis distalis bent toward the projections of the vesica is also observed in $L$. vandoesburgi. Within the hatchet-lobed group, L. incisus and L. vandoesburgi share the pronotal margin posterior to the lobes expanded on each side into an obtuse projection. The incision between each lobe and the anterolateral margin of the pronotum is deepest in L. incisus, reaching half the width of an eye (Fig. 10; RoLsTon 1983, Figs. 1, 8). Lincus incisus can also be distinguished from $L$. vandoesburgi by the more convex apical margin of the posterolateral angles of the pygophore, and by a more developed median projection (Figs. 11-12, mp; for L. vandoesbugi see Rolston 1983, Fig. 2). Among the other species in the hatchet-lobed group with known males, $L$. incisus differs from $L$. sinuosus by the median projec- 
tion below the apical margin of the posterolateral angles of the pygophore (Figs. 11-12, mp; for L. sinuosus see RoLsTon 1983, Fig. 17); from L. convexus and L. securiger by the more developed median projection and the ventral opening of the pygophore broader and shallower (Figs. 11-12, mp, vr; for L. convexus and L. securiger see RoLsTon 1983, Figs. 23 and 26). Notwithstanding the placement of $L$. incisus within the "hatchet-lobed" group, it is noticeable that the shape of segment $\mathrm{X}$, with an expanded and flattened apex, is also a feature of some species of the "bigeyed" group (RoLsTon 1983), such as Lincus lethifer Dolling, 1984, Lincus substyliger Rolston, 1983 and Lincus subuliger Breddin, 1908. Lincus incisus is recorded for the first time in Brazil.

\section{ACKNOWLEDGMENTS}

We thank the curators of the scientific collections for the loan of specimens. We also thank Conselho Nacional de Desenvolvimento Científico e Tecnológico (CNPq) for the scholarships granted to T.A. Garbelotto (process 142448/2011-7), Coordenação de Aperfeiçoamento de Pessoal de Nível Superior (CAPES) to T. Roell, and Universidade Federal do Rio Grande do Sul (UFRGS) to I.C. Winter and the funding from CNPq (process 305367/2012-9) as fellowship grant to L.A. Campos.

\section{LITERATURED CITED}

BAKER AD (1931) A study of the male genitalia of Canadian species of Pentatomidae. Canadian Journal of Research 4(3): 148-220. doi: 10.1139/cjr31-013

Camargo EP (1999) Phytomonas and other trypanosomatid parasites of plants and fruit. Advances in Parasitology 42: 29-112. doi: 10.1016/S0065-308X(08)60148-7

Campos LA, Grazia J (2006) Análise cladística e biogeografia de Ochlerini (Heteroptera, Pentatomidae, Discocephalinae). Iheringia, Série Zoologia 96(2): 147-163. doi: 10.1590/ S0073-47212006000200004

Couturier G, KaHn F (1989) Bugs of Lincus spp. vectors of Marchitez and Hartrot (oil palm and coconut diseases) on Astrocaryum spp., Amazonian native palms. Principes 33(1): 19-20.

Couturier G, Kahn F (1992) Notes on the insect fauna on two species of Astrocaryum (Palmae, Cocoeae, Bactridinae) in Peruvian Amazonia, with emphasis on potential pests of cultivated palms. Bulletin de l'Institut Français d'Études Andines 21(2): 715-725.

Desmier de Chenon R (1984) Recherches sur le genre Lincus Stål, Hemiptera Pentatomidae Discocephalinae, et son role éventuel dans la transmission de la Machitez du palmier à huile et du Hart-Rot du cocotier. Oléagineux 39(1): 1-6.

Di Lucca AGT, Chipana EFT, Albújar MJT, Peralta WT, Piedra YCM, ZeladA JLA (2013) Slow wilt: another form of Marchitez in oil palm associated with trypanosomatids in Peru. Tropical Plant Pathology 38(6): 522-533. doi: 10.1590/S198256762013000600008 .
DolLing WR (1984) Pentatomid bugs (Hemiptera) that transmit a flagellate disease of cultivated palms in South America. Bulletin of Entomological Research 74(3): 473-476. doi: 10.1017/S000748530001573X

Dupuis C (1970) Heteroptera, p. 190-208. In: Tuxen SL (Ed.). Taxonomist's glossary of genitalia of insects. Copenhagen, Munksgaard, 359p.

EVENHUIS NL (2014) Abbreviations for insect and spider collections of the world. Available at: http://hbs.bishopmuseum.org/ codens/codens-inst.html [Accessed: 12 November 2014]

Garbelotto TA, Campos LA, Grazia J (2013) Cladistics and revision of Alitocoris with considerations on the phylogeny of the Herrichella clade (Hemiptera, Pentatomidae, Discocephalinae, Ochlerini). Zoological Journal of the Linnean Society 168(3): 452-472. doi: 10.1111/zoj.12032

HOWARD FW (2001) Sap-feeders on palms, p. 109-232. In: HOWARD FW, Moore D, Giblin-Davis RM, Abad RG (Eds). Insects on palms. New York, CABI Publishing, XIII+403p. doi: 10.1079/ 9780851993263.0109

Llosa JF, Couturier G, Kahn F (1990) Notes on the ecology of Lincus spurcus and L. malevolus (Heteroptera: Pentatomidae: Discocephalinae) on Palmae in forests of Peruvian Amazonia. Annales de laSociété Entomologique de France (Nouvelle Série) 26(2): 249-254.

Mitchell PL (2004) Heteroptera as vectors of plant pathogens. Neotropical Entomology 33(5): 519-545. doi: 10.1590/ S1519-566X2004000500001

Panizzi AR, McPherson Je, Javahery JM, McPherson RM (2000) Stink Bugs (Pentatomidae), p. 421-474. In: Schaefer CW, PANIZZI AR (Eds). Heteroptera of economic importance. Boca Raton, CRC Press, 856p.

Perthuis B, Desmier de Chenon R, Merland E (1985) Mise en évidence du vecteur de la Marchitez sorpresiva du palmier à huile, la punaise Lincus lethifer Dolling (Hemiptera Pentatomidae Discocephalinae). Oléagineux 40(10): 473-475.

Rolston LH (1983) A revision of the genus Lincus Stål (Hemiptera: Pentatomidae: Discocephalinae: Ochlerini). Journal of the New York Entomological Society 91(1): 1-47.

Rolston LH (1989) Three new species of Lincus (Hemiptera: Pentatomidae) from palms. Journal of the New York Entomological Society 97(3): 271-276.

Rolston LH (1992) Key and dignoses for the genera of Ochlerini (Hemiptera: Pentatomidae: Discocephalinae). Journal of the New York Entomological Society 100(1): 1-41.

STÅL C (1867) Bildrag till Hemipterernas systematik. Conspectus generum Pentatomidum Americae. Öfversigt af Kongliga Vetenskaps-Akademiens Förhandlingar 24(7): 522-532.

Submitted: 13 November 2014

Received in revised form: 27 January 2015

Accepted: 28 February 2015

Editorial responsibility: Ângelo Parise Pinto 